\title{
Genetic structure and phylogeography of pine shoot beetle populations (Tomicus destruens and T. piniperda, Coleoptera Scolytidae) in Italy
}

\author{
Massimo FaCCOLI*, Alessia Piscedda, Paola Salvato, Mauro Simonato, Luigi Masutti, \\ Andrea BATTISTI
}

Department of Environmental Agronomy and Crop Productions - University of Padua, Agripolis - Viale dell'Università 16/a, 35020 Legnaro (PD), Italy

(Received 4 May 2004; accepted 15 December 2004)

\begin{abstract}
Tomicus are among the most dangerous pine pests. In this paper we assess the genetic structure of some Italian Tomicus populations, and the possible sympatry of $T$. destruens and T. piniperda. A fragment $358 \mathrm{bp}$ long of the mitochondrial DNA relative to the COI was investigated in eight populations by SSCP analyses and sequencing. In the sampled populations T. destruens and T. piniperda were not found to be sympatric. T. destruens populations of southern and central Italy strongly differ from a population of northern Italy. The phylogeographic analysis of $T$. destruens populations in Europe is geographically structured, probably due to the fragmentation of the host pine ranges. The populations of $T$. piniperda are polymorphic, with haplotypes occurring also in Europe and Asia. T. piniperda populations seem to be genetically unstructured because of both the continuous distribution area of its main host (Pinus sylvestris) and the international trade of pine timber.
\end{abstract}

mtDNA / SSCP / Scolytidae / pine / phylogeography

Résumé - Structure génétique et phylogéographie des populations de Tomicus destruens et $\mathbf{T}$. piniperda (Coleoptera Scolytidae) en Italie. Le genre Tomicus figure parmi les espèces les plus dangereuses pour les forêts de pins. La structure génétique de huit populations italiennes de $T$. destruens et $T$. piniperda a été étudiée, ainsi que la sympatrie possible des deux espèces. Un fragment de 358 pb de l'ADN mitochondrial relatif au COI a été amplifié, séquencé et soumis à une analyse par SSCP. Aucun cas de sympatrie n'a été observé entre $T$. destruens et $T$. piniperda. Les populations de $T$. destruens d'Italie méridionale et centrale sont très différentes d'une population d'Italie du Nord. T. destruens montre une structuration géographique probablement liée à la distribution fragmentée des pins hôtes. Par contre, les populations de $T$. piniperda sont très polymorphes, sans doute à cause de la distribution continue de son principal hôte, le pin sylvestre, ainsi qu'au commerce international de bois.

\section{INTRODUCTION}

The pine shoot beetles belonging to the genus Tomicus Latreille (Coleoptera Scolytidae) are among the most dangerous insects living in Eurasian pine forests [23]. These bark beetles have a major role in the decline of many pine forests growing in both Europe and Mediterranean countries, including Northern Africa. Among the six species belonging to the genus Tomicus, only T. piniperda (Linnaeus, 1758), T. destruens (Wollaston, 1865) and T. minor (Hartig, 1834) occur in Europe [21]. Tomicus piniperda is widespread in Eurasia and it has been recently introduced in North America [13]. Tomicus destruens occurs in all circum-Mediterranean regions and Madeira Islands, whereas Tomicus minor occurs in Europe and Asia.
For a long-time $T$. piniperda and $T$. destruens were considered as synonyms [27], even if attempts to separate the two species were done [18, 21]. However, recent papers reported both morphological and genetic characters useful for the separation of the two siblings $[11,15,16]$. Nevertheless, species determination by morphological analysis is still extremely difficult, and the genetic support is needed. In addition, the sympatry of the two Tomicus in some Mediterranean countries [11, 15] makes the identification even more difficult.

The species confusion has made it possible that the largest part of data published in Mediterranean region, where T. destruens is more common, reports $T$. piniperda as the investigated species $[3-5,12,19,25,26,38]$. From this point of view, data concerning many populations of $T$. destruens are confused and would need reconsideration. Finally, the lack of specificity of

\footnotetext{
* Correponding author: massimo.faccoli@unipd.it
} 


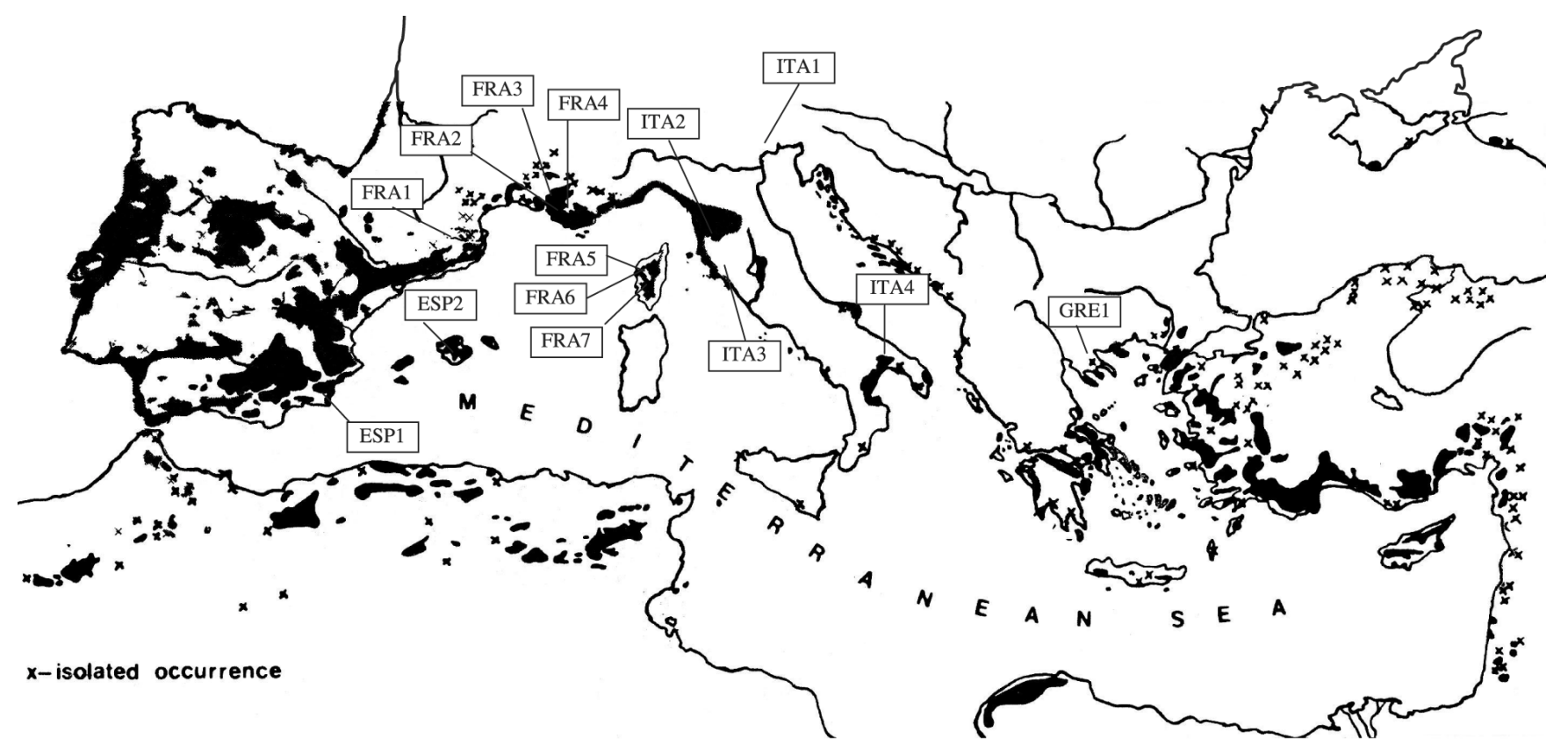

Figure 1. Sampling sites of Italian populations of T. destruens (ITA1-4) and locations of the populations used for the phylogeographic analysis. The natural range of the potential host pine species $P$. pinea, P. pinaster, P. brutia and P. halepensis (modified from Critchfield and Little [7]) is given in the background. The actual range is wider for the artificial spread of pine in plantations, as it is evident for the population ITA1. A three letters abbreviation corresponding to the country and a locality identification number indicates the sites where the populations were sampled.

Tomicus species for a host plant does not allow to use host species as a tool for insect identification, although T. destruens was found only on Mediterranean pines so far, whereas T. piniperda was collected from both continental (Pinus sylvestris and $P$. nigra) and Mediterranean pines (P. pinaster) [11, 15].

Recently, Ritzerow et al. [24] have used a phylogeographic approach to the analysis of mtDNA genetic data from several Eurasian populations of $T$. piniperda. The study suggests that only very long distances or important geographic barriers, like the Pyrenees, are relevant to the separation of the populations and the consequent differentiation of haplotypes. In this respect, comparative phylogeography permits the investigation of biogeographic questions on spatial and temporal scales that are smaller than those typically addressed with other approaches [2]. Moreover, the phylogeography is useful in elucidating contemporary patterns of evolutionary subdivision within species and species complexes, providing novel insights into the understanding of biotic diversification [1].

In this paper, we want to use this approach to study evolutionary history and the origin of Italian populations of T. destruens and $T$. piniperda, by genetic markers of mtDNA. The central geographic position of Italy in the Mediterranean could be important for understanding the genetic structure of Tomicus populations occurring in southern Europe. For example, during the last glaciation Italian pine forests could have been a refuge area for Tomicus populations, as suggested for other bark beetle species [31]. In addition, we want to test the possible sympatry of $T$. destruens and $T$. piniperda in Italian transition areas between continental and Mediterranean pine forests.

\section{MATERIALS AND METHODS}

\subsection{Sample collection and DNA isolation}

Adults of Tomicus were collected from eight different populations living in pine forests growing in Italy (Fig. 1 and Tab. I). The insects were collected from recently infested pine logs, and firstly identified by morphological characters [21]. The genomic DNA was extracted following a salting out protocol [20].

\subsection{Mitochondrial DNA analysis}

A fragment of about $490 \mathrm{bp}$ of the Cytochrome Oxidase I (COI) was amplified using the lepidopteran mitochondrial primers C1J2441 [29] for both the Tomicus species, and C1N2934, and C1N2937 for $T$. destruens and $T$. piniperda, respectively [16]. Once sequenced, the COI fragments were used to design a Tomicus specific primer TMC2 (5'-ATTGATGAAATAATATTTCATATAAAATATGC-3').

The SSCP analysis was performed on a COI fragment 358 bp long, which was amplified using the primers C1J2441 and TMC2. Template DNA $(4 \mu \mathrm{L})$ were used in $12.5 \mu \mathrm{L}$ of PCR reaction mix, containing $0.5 \mathrm{U}$ of Taq DNA polymerase (Promega ${ }^{\circledR}$ ), $1 \times$ reaction buffer, $1.5 \mathrm{mM} \mathrm{MgCl}_{2}, 0.2 \mathrm{mM}$ of each dNTP's and $0.5 \mu \mathrm{M}$ of each primer. The target region was amplified by 37 cycles of PCR on a Perkin Elmer DNA Thermal Cycler $9600^{\circledR}$. Following a pre-denaturation step of 3 min at $94{ }^{\circ} \mathrm{C}$, the thermal profile included denaturation for $1 \mathrm{~min}$ at $94{ }^{\circ} \mathrm{C}$, annealing for $1 \mathrm{~min}$ at $50{ }^{\circ} \mathrm{C}$, and extension for $1 \mathrm{~min}$ at $72{ }^{\circ} \mathrm{C}$. A final elongation step $\left(5 \mathrm{~min}\right.$ at $\left.72^{\circ} \mathrm{C}\right)$ was also performed. Then, $3 \mu \mathrm{L}$ of the PCR reaction were heat denatured and electrophoresed through a $11 \%$ polyacrylamide gel (29:1 acrylamide:bisacrylamide). The runs were performed at $10{ }^{\circ} \mathrm{C}$ for $10000 \mathrm{~V} / \mathrm{h}$ in a $23 \mathrm{~cm}$ long vertical apparatus. The samples were classified into distinct mobility classes 
Table I. Characteristics of the Tomicus populations sampled in Italy. $N$ : number of insects collected in each population; Host pine: P.P.: Pinus pinaster, P.D.: Pinus pinea, P.H.: Pinus halepensis, P.N.: Pinus nigra, P.S.: Pinus sylvestris.

\begin{tabular}{|c|c|c|c|c|c|c|c|c|}
\hline Species & Code & $N$ & Locality & Lat. $\mathrm{N}$ & Long. E & $\begin{array}{c}\text { Altitude } \\
\text { m a.s.l. }\end{array}$ & Host pine & Date \\
\hline \multirow{4}{*}{ T. destruens } & ITA1 & 19 & Valle Vecchia (VE) & $45^{\circ} 54^{\prime}$ & $12^{\circ} 36^{\prime}$ & 3 & P.P. & $03 / 2001$ \\
\hline & ITA2 & 17 & Poggio Valicaia (FI) & $43^{\circ} 34^{\prime}$ & $11^{\circ} 13^{\prime}$ & 370 & P.P. & $04 / 2002$ \\
\hline & ITA3 & 18 & Alberese (GR) & $42^{\circ} 40^{\prime}$ & $11^{\circ} 06^{\prime}$ & 42 & P.D. & $03 / 2002$ \\
\hline & ITA4 & 16 & Ginosa (TA) & $40^{\circ} 34^{\prime}$ & $16^{\circ} 45^{\prime}$ & 240 & P.H. & $03 / 2002$ \\
\hline \multirow{4}{*}{ T. piniperda } & ITA5 & 20 & Villasantina (UD) & $46^{\circ} 25^{\prime}$ & $12^{\circ} 55^{\prime}$ & 363 & P.S. & $04 / 2001$ \\
\hline & ITA6 & 16 & Passo del Bocco (GE) & $44^{\circ} 20^{\prime}$ & $9^{\circ} 23^{\prime}$ & 956 & P.N. & $04 / 2002$ \\
\hline & ITA7 & 12 & Rocciamelone (TO) & $45^{\circ} 10^{\prime}$ & $7^{\circ} 08^{\prime}$ & 1600 & P.S. & $05 / 2002$ \\
\hline & ITA8 & 20 & Sonico (BS) & $46^{\circ} 11^{\prime}$ & $10^{\circ} 23^{\prime}$ & 1010 & P.S. & $11 / 2002$ \\
\hline
\end{tabular}

(haplotypes) according to their SSCP pattern. In addition, as two mobility classes were difficult to distinguish, the attribution of individuals to each class was confirmed by digesting the amplified DNA with the restriction enzyme Bst1107I, which cuts at a diagnostic site, followed by an agarose gel electrophoresis.

All the rare haplotypes and a random sample of the more frequent mobility classes, for a total of 40 individuals (16 of T. destruens, 24 of $T$. piniperda), were sequenced. The PCR products were then purified using a pre-sequencing kit (Amersham-Pharmacia Biotech ${ }^{\circledR}$ ). Finally, purified DNA was sequenced using a BygDye Terminators 3.0 Cycle Sequencing kit (Applied Biosystems ${ }^{\circledR}$ ) and it was run in an ABIPRISM 3700 DNA Analyser (Applied Biosystem ${ }^{\circledR}$ ).

\subsection{Analysis of the genetic data}

The genetic sequences of each specimen were aligned using the ClustalX ${ }^{\circledR}$ program [37] and then analysed by MEGA $2.1^{\circledR}[17]$. We also investigated genetic variation within single populations of the two species. The degree of polymorphism of each population was determined using the program Arlequin $2.0^{\circledR}$ [28], and expressed as haplotype $(\mathrm{h})$ and nucleotide diversity $(\pi)$. The sequences were aligned with those of $T$. destruens and T. piniperda available in GenBank.

In order to evaluate the neutrality and mutation/drift equilibrium of the investigated sequences, i.e. the degree of homogeneity of the population, we also tested the distance from the neutrality expectations using both Tajima ( $D$ value) [32] and Ewens-Watterson tests ( $F$ value) $[10,39]$, as implemented in Arlequin $2.0^{\circledR}$. For mt DNA, high values of $F$ and negative values of $D$ indicate the occurrence of few common haplotypes [6]; low $F$ values and positive $D$ values may be expected in the presence of subdivided populations or migration [30]. The haplotype networks for the COI data was constructed using the software TCS 1.18. The TCS program creates a haplotype network using Statistical Parsimony [34], which outputs the 95\% plausible set of most parsimonious linkages among haplotypes. Ambiguous linkages are depicted by "loops" in the haplotype network.

To have a comparison in a wider phylogeographic context, the $T$. destruens sequences were compared with those deposited in GenBank. Because the COI region sequenced in our analysis was not the same of those deposited in GenBank, the alignment was reduced to $185 \mathrm{bp}$. Differently, the whole Italian sequences of $358 \mathrm{bp}$ of $T$. piniperda were compared with the corresponding part of those reported by Ritzerow et al. [24].

The haplotype network was then nested into a series of clades following Templeton et al. [33] and Templeton and Sing [35] and used for nested clade analysis using the GeoDis 2.0 program [22]. Nested clade analysis provides an objective statistical framework for discrim- inating among historical (e.g., range expansion and fragmentation) and recurrent (e.g., gene flow and drift) processes that may explain the observed distribution of genetic variation. The geographical data were quantified as $D c$ (geographical spread of a particular clade) and $D n$ (distribution of a given clade relative to the sister clades). This analysis tested the association of clades with geographical locations, the significance of the distances $D c$ and $D n$, as well as the contrasts between interior-tip subgroups. The statistical significance of these measures was determined using random permutation tests, which simulate the null hypothesis of a random geographical distribution for all clades within a nesting category, given the marginal clade frequencies and sample sizes per locality. The interpretation of the observed distances was carried out using the revised inference key by Templeton [36] (accessible at: http://InBio.byu.edu/Faculty/kac/crandall_lab/geodis.htm).

\section{RESULTS}

The morphological and genetic analysis of the eight Italian populations allowed to attribute all the individuals within a population to one of the two species, excluding the sympatric occurrence of the two Tomicus in the study sites (Tab. I). The investigated populations showed a polymorphism associated to several classes of mobility, i.e. haplotypes. The SSCP analyses carried out on 159 specimens clearly distinguished seven haplotypes for $T$. destruens and eleven for $T$. piniperda (Tab. II). The sequencing of all the variants confirmed the presence of at least one nucleotide substitution from one to another. Moreover, the sequence analysis of five (T. destruens) and eight ( $T$. piniperda) individuals sharing the same haplotype in different populations confirmed the accuracy of the SSCP method. The sequence of each different haplotype has been deposited in GenBank under accession numbers AY796318 AY796332. The analysed fragment of COI (358 bp) revealed seven ( 7 transitions and 1 transversion) and thirteen variable sites (13 transitions and no transversion) for T. destruens and T. piniperda, respectively (Tab. III). For both species all the mutations were synonymous.

The number of private haplotypes was 3 in $T$. destruens (A, C, G) and 6 in T. piniperda $(4,5,6,8,10,11)$ (Tab. II).

Haplotype diversity $(h)$ and nucleotide diversity $(\pi)$ for each population are showed in Table IV. 
Table II. Mitochondrial haplotypes found in Tomicus destruens and Tomicus piniperda collected from different pine stands. N: total specimens per population.

\begin{tabular}{|c|c|c|c|c|c|c|c|c|c|c|c|c|c|}
\hline Species & Population & $N$ & & & & & & Haplotyl & & & & & \\
\hline \multirow{6}{*}{ T. destruens } & & & $\mathrm{A}$ & & $\mathrm{B}$ & $\mathrm{C}$ & & $\mathrm{D}$ & $\mathrm{E}$ & & F & & $\mathrm{G}$ \\
\hline & & & AY796318 & & AY796319 & AY796320 & & AY796321 & AY796322 & & AY796323 & & AY796324 \\
\hline & ITA1 & 19 & 12 & & 6 & - & & - & - & & 1 & & - \\
\hline & ITA2 & 17 & - & & 13 & 1 & & 1 & 1 & & 1 & & - \\
\hline & ITA3 & 18 & - & & 14 & - & & 2 & 1 & & 1 & & - \\
\hline & ITA4 & 16 & - & & 10 & - & & - & - & & 4 & & 2 \\
\hline \multirow{6}{*}{ T. piniperda } & & & 1 & 2 & 3 & 4 & 5 & 6 & 7 & 8 & 9 & 10 & 11 \\
\hline & & & & & AY796325 & AY796326 & AY796327 & AY796328 & AY796329 & AY796330 & & AY796331 & AY796332 \\
\hline & ITA5 & 20 & 18 & 1 & 1 & - & - & - & - & - & - & - & - \\
\hline & ITA6 & 16 & 9 & 6 & - & - & - & - & 1 & - & - & - & - \\
\hline & ITA7 & 12 & 6 & - & 1 & - & 1 & - & - & - & 1 & 2 & 1 \\
\hline & ITA8 & 20 & 10 & - & - & 3 & - & 4 & 1 & 1 & 1 & - & - \\
\hline
\end{tabular}

Table III. Variable nucleotide sites in the 7 haplotypes of $T$. destruens and 11 haplotypes of T. piniperda defined on the basis of 358 bp of the mitochondrial DNA Cytochrome Oxidase I. The numbers indicate variable positions corresponding to positions of haplotype B for T. destruens and haplotype 1 for T. piniperda.

\begin{tabular}{|c|c|c|c|c|c|c|c|c|c|c|c|c|c|c|c|c|c|c|c|c|c|}
\hline \multirow[b]{3}{*}{ Haplotype } & \multicolumn{7}{|c|}{ T. destruens } & \multirow[b]{3}{*}{ Haplotype } & \multicolumn{13}{|c|}{ T. piniperda } \\
\hline & \multicolumn{7}{|c|}{ Position } & & \multicolumn{13}{|c|}{ Position } \\
\hline & 85 & 175 & 217 & 250 & 328 & 340 & 349 & & 28 & 46 & 111 & 150 & 175 & 181 & 223 & 229 & 250 & 320 & 331 & 351 & 354 \\
\hline B & $\mathrm{C}$ & A & G & $\mathrm{C}$ & $\mathrm{C}$ & A & $\mathrm{C}$ & 1 & $\mathrm{~T}$ & $\mathrm{~T}$ & $\mathrm{G}$ & $\mathrm{C}$ & A & $\mathrm{T}$ & $\mathrm{C}$ & A & $\mathrm{C}$ & $\mathrm{T}$ & $\mathrm{G}$ & $\mathrm{T}$ & $\mathrm{C}$ \\
\hline G & . & . & . & $\mathrm{T}$ & . & . & . & 9 & . & . & . & . & . & . & . & . & $\mathrm{T}$ & . & . & . & . \\
\hline D & . & . & A & . & . & . & . & 2 & . & . & . & . & . & $\mathrm{C}$ & . & . & . & . & . & . & . \\
\hline $\mathbf{E}$ & . & . & $\mathrm{T}$ & . & . & . & . & 3 & . & . & . & . & . & . & . & . & . & $\mathrm{C}$ & . & . & . \\
\hline $\mathbf{F}$ & . & . & . & . & $\mathrm{T}$ & . & . & 5 & $\mathrm{C}$ & . & . & . & G & . & . & . & . & $\mathrm{C}$ & . & . & . \\
\hline $\mathrm{C}$ & . & G & . & . & . & . & $\mathrm{T}$ & 7 & $\mathrm{C}$ & . & A & $\mathrm{T}$ & G & . & . & . & . & $\mathrm{C}$ & . & . & . \\
\hline \multirow[t]{5}{*}{$\mathbf{A}$} & $\mathrm{T}$ & . & . & . & $\mathrm{T}$ & $\mathrm{G}$ & $\mathrm{T}$ & 11 & . & . & . & . & $\mathrm{G}$ & . & . & . & . & $\mathrm{C}$ & . & . & . \\
\hline & & & & & & & & 8 & . & . & . & . & $\mathrm{G}$ & . & $\mathrm{T}$ & $\mathrm{G}$ & . & $\mathrm{C}$ & . & . & . \\
\hline & & & & & & & & 6 & . & $\mathrm{C}$ & . & . & $\mathrm{G}$ & . & . & . & . & $\mathrm{C}$ & A & $\mathrm{C}$ & . \\
\hline & & & & & & & & 4 & . & . & . & . & . & . & . & . & & $\mathrm{C}$ & A & . & . \\
\hline & & & & & & & & 10 & . & . & . & . & . & . & . & . & & $\mathrm{C}$ & A & . & $\mathrm{T}$ \\
\hline
\end{tabular}

Table IV. Haplotype and nucleotide diversity with result of the Tajima and Ewens-Watterson neutrality tests on the analysed COI segment in Tomicus Italian population. $F_{\mathrm{obs}}-F_{\exp }$ is the difference between the observed and expected homozygosity $(* P<0.05, * * P<0.01)$.

\begin{tabular}{lccccc}
\hline Populations & & Haplotype diversity $(h)$ & Nucleotide diversity $(\pi)$ & \multicolumn{2}{c}{ Tajima’s } \\
& & & 0 statistic & $F_{\text {obs }}-F_{\text {exp }}$ \\
\hline T. destruens & ITA1 & $0.5263( \pm 0.0887)$ & $0.005449( \pm 0.003609)$ & $2.02065^{*}$ & -0.05421 \\
& ITA2 & $0.4265( \pm 0.1468)$ & $0.001630( \pm 0.001542)$ & $-1.55781^{*}$ & $0.25791^{* *}$ \\
& ITA3 & $0.3987( \pm 0.1379)$ & $0.001172( \pm 0.001250)$ & -0.68482 & $-0.1927^{*}$ \\
& ITA4 & $0.5667( \pm 0.1090)$ & $0.001775( \pm 0.001636)$ & $-1.51284^{*}$ & $0.25559^{* *}$ \\
\hline T. piniperda & ITA5 & $0.1947( \pm 0.1145)$ & $0.000560( \pm 0.000809)$ & -1.2933 & -0.01183 \\
& ITA6 & $0.5750( \pm 0.0799)$ & $0.003175( \pm 0.002433)$ & -0.41098 & 0.06363 \\
& ITA7 & $0.7576( \pm 0.1221)$ & $0.004990( \pm 0.003487)$ & -0.44013 & 0.02585 \\
\hline
\end{tabular}




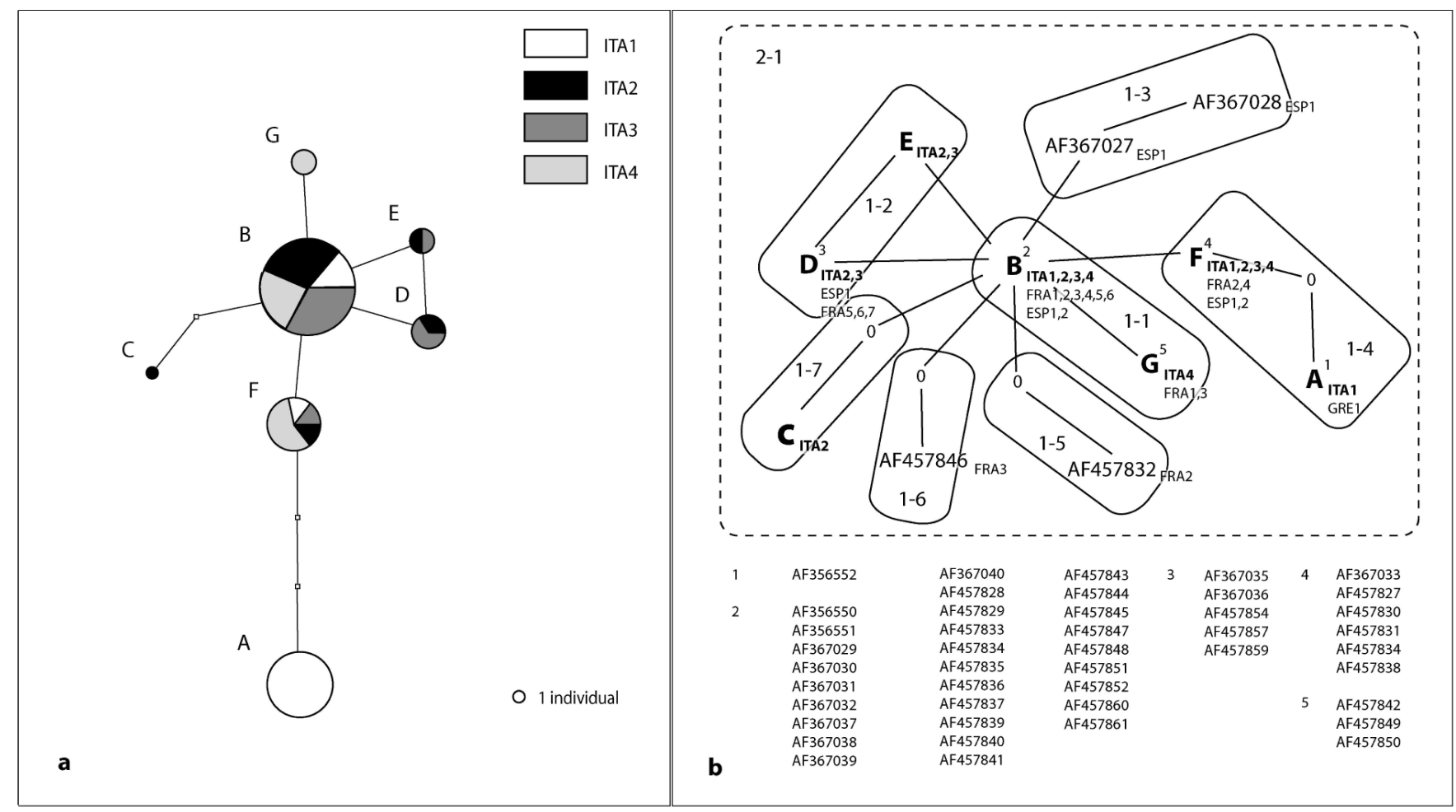

Figure 2. (a) Italian haplotype network of T. destruens based on 358bp. Each line represents a mutational step; small squares refer to missing or theoretical haplotypes. Circles represent haplotypes with size proportional to relative frequencies; sectors of different colours refer to absolute number of haplotype counts for each population. (b) Haplotype network based on mutational differences in the COI mtDNA sequences of T. destruens populations. Italian haplotypes are reported as bold letters, whereas haplotypes from GenBank are indicated by their accession numbers. The list below the figure reports the haplotypes of $T$. destruens deposited in GenBank and matching the Italian ones for the 185bp allowed by the overlapping. The sites in which haplotypes were found are indicated with the country abbreviation and the locality identification number (see Fig. 1). In addition, the nested clade analysis is reported: the clades are identified using a two numbers system with the first number referring to the nesting hierarchy and the second is the clade identification number. "0" means a missing or theoretical haplotype.

For T. destruens the Tajima's $D$ value was lower than expected in two populations (ITA2 and ITA3), but statistical significance was reached only in ITA2 (Tab. IV). However, integrating the Tajima's test with the Ewens-Watterson test ( $F$ value), also the ITA3 population showed a homozygosity degree significantly higher than in expected neutrality conditions (Tab. IV). $D$ value was significantly higher than expected only for the ITA1 population (Tab. IV). Both tests indicated that ITA4 was in equilibrium ( $F$ and $D$ value close to zero).

Concerning $T$. piniperda all populations show Tajima's $D$ values lower than expected, but only the ITA5 population shows statistical significance (Tab. IV). In addition the population ITA6 seems to be in equilibrium having both $F$ and $D$ value close to zero.

The haplotypes B and F of T. destruens were the most common. The haplotype A was the most differentiated from the haplotypes B and F (three and four mutational steps respectively) (Fig. 2a). The haplotype $G$ was occurring only in the southern population of T. destruens living on Pinus halepensis. Haplotypes C, D and E were found only in central Italy. The analysis of European sequences showed that the haplotypes B and $\mathrm{F}$ were the most common found in populations of $T$. destruens sampled in western Mediterranean basin (Italy, France and Spain) (Fig. 2b). The haplotype A was similar to a haplotype found in Greece (accession number AF356552) (Fig. 2b), suggesting its probable eastern origin. The comparison with sequences deposited in GenBank showed that the haplotype $G$ was already found in France on the same host tree [15]. Finally, the haplotypes $\mathrm{C}$ and $\mathrm{E}$ were found only in Italy. Other four private haplotypes occurred in continental France and Spain (Fig. 2b).

The nested clade design included 11 haplotypes across two nesting levels (Fig. 2b). At the total cladogram level the analysis showed that there was a restricted gene flow excepted for the clade 1-4, which includes the haplotype A occurring only in North Italy and Greece, showing a long-distance dispersal (Fig. 2b).

In $T$. piniperda, the haplotype 1 was the most common, whereas the other haplotypes occurred in very few individuals (Fig. 3 and Tab. IIb). The populations sampled at the southern edge of host's range (ITA5 and ITA6) were much less heterogeneous than populations collected within the range (ITA7 and ITA8), which shared most of the rare haplotypes. On a wider scale, Italian haplotypes 1, 2 and 9 occurred also in Europe, in particular as fragments of haplotypes I, II, VII for 1, IV for 2, and VIII, IX for 9 [24]. The other eight haplotypes were found 


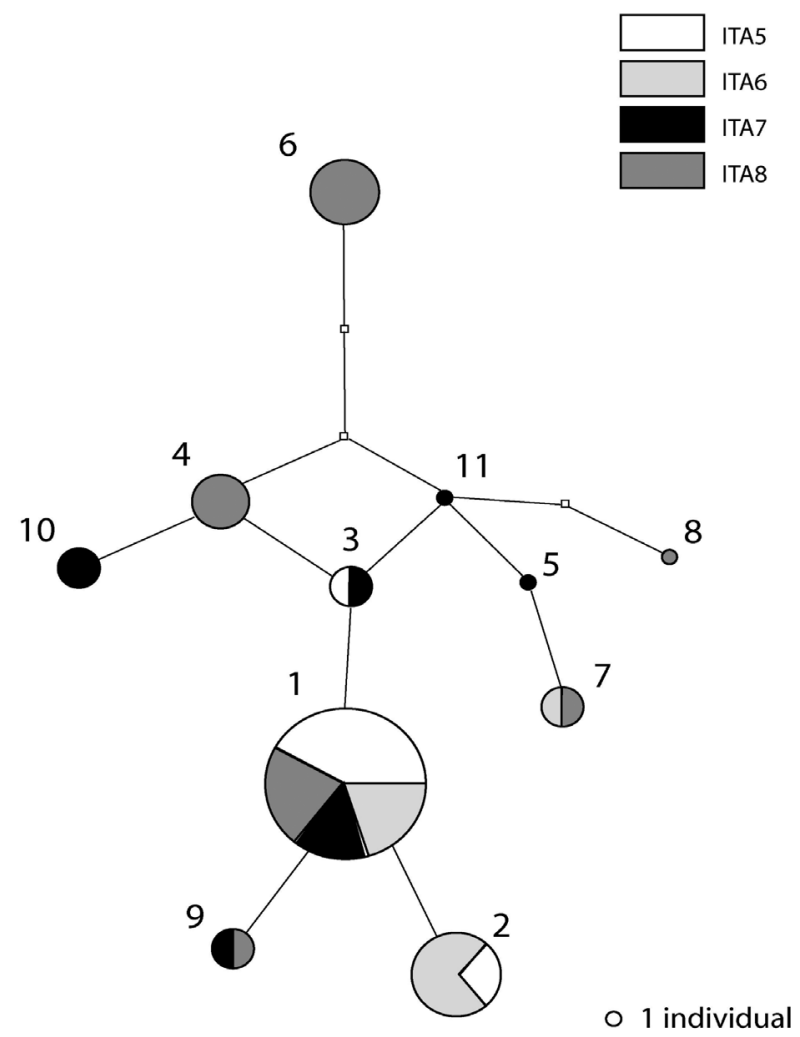

Figure 3. Italian haplotype network of T. piniperda based on $358 \mathrm{bp}$ (for figure explanation see Fig. 2).

only in Italy. The nested clade analysis gave as result an inconclusive outcome, showing a low phylogeographic structure for T. piniperda.

\section{DISCUSSION}

In this paper we show that the two sibling species of pine shoot beetle, Tomicus destruens and Tomicus piniperda, differ strongly in relation to the genetic structure of their populations in Italy as well as in Europe. T. destruens is characterized by a strong phylogeographic structure, whereas this was not observed for T. piniperda. As T. destruens has been shown to be associated exclusively with Mediterranean pine species [21], the high fragmentation of the hosts range seems to be the most likely factor explaining the separation of the populations. Conversely, the continuous range of the main host of $T$. piniperda ( $P$. sylvestris), and the possibility for this species to colonize other hosts and even Mediterranean pines [11, 15], appear to be the main reason for the lack of genetic structure [24], in spite of the very numerous private haplotypes found in Italy as well as in other regions.

In this study Tomicus destruens and $T$. piniperda were not found to be sympatric, not even in the transition areas from coastal to alpine stands, such as in ITA1 and ITA5 populations. $T$. destruens was found only on Mediterranean pine species
(Pinus pinea, P. pinaster and P. halepensis), whereas Tomicus piniperda was collected only from continental pine species such as $P$. nigra and $P$. sylvestris. The phylogeographic analysis of $T$. destruens shows that the populations of France, Italy and Spain are well structured, having their own haplotypes. However, it was possible to verify that some Italian haplotypes were already found in Europe. In particular, the haplotypes B and $\mathrm{F}$ were the most common haplotypes found in all the investigated Italian populations, as well as in many French and Spanish populations $[11,15,16]$, suggesting their older origin. Besides, the haplotype $\mathrm{G}$ found in insects sampled from Pinus halepensis (ITA4), was found also in France from the same host tree [15], indicating a possible differentiation in relation to this host or its habitat, which is typical of warm and dry Mediterranean areas.

The genetic structure of the northern population (ITA1) is quite different from those of the other investigated populations (Fig. 2b). The haplotype A was the only found in four specimens of a Greek population [16], suggesting a Balkan origin of the ITA1 population. In fact, this population originates from a coastal plantation of Mediterranean pines about 50 years old, belonging to a system of plantations created to protect the Adriatic coasts since the Roman time, about 2000 years ago [8]. It appears that part of Tomicus population probably came from the eastern coast of Adriatic sea (haplotype A), whereas a part came from the south-western Adriatic coast, through the coastal system of pine plantations (haplotypes B and F). In this respect, the ITA 1 population seems to occur in a contact area between western and eastern parts of Mediterranean basin. This hypothesis is confirmed by the high $D$ value (Tab. IV), which is usually expected either from populations affected by strong immigration or divided in sub-populations having a high number of haplotypes and a heterogeneous genetic pool [30].

Finally, the haplotypes $\mathrm{C}$ and $\mathrm{E}$ (from ITA2 and ITA3) seem to be characteristic of central Italy. In this respect, the results obtained with Tajima's test and the Ewens-Watterson test for the ITA 2 and ITA3 populations (Tab. IV) can be expected in populations having had either a bottleneck [32] or a rapid growth from a fewer number of individuals [30], as already suggested by Kerdelhué et al. [15]. However, populations from central and southern Italy share most haplotypes with French populations [15], to which they are connected through the continuous distribution of pine stands along the coast.

The analysis of new populations from the eastern Mediterranean and northern Africa could shed more light on the genetic structure of $T$. destruens, as well as the analysis of populations established in artificial plantations of pines along the Mediterranean coasts could provide useful information on the insect dispersal and associated gene flow.

Concerning $T$. piniperda, the high number of haplotypes (11) found in the Italian populations can be explained by the fact that many individuals were analysed for each population, increasing the probability to find new haplotypes. Another possible explanation of the high number of isolated haplotypes ( 8 out of 11) can be found in the role played by the Alps during the last glaciation, as they were a refuge area for many European insect populations forced to move southward, looking for more suitable climatic conditions [14]. This migration had therefore increased the genetic pool of $T$. piniperda in Italy, as it 
has been observed also for the spruce bark beetle Ips typographus, which also has a large Palaearctic diffusion [31]. Similar considerations were reported by Ritzerow et al. [24], who suggest the high polymorphism of $T$. piniperda as due to the existence of several distinct refugial areas during the last ice age. A fragmentation and prolonged genetic isolation of European populations during the last glacial period could have led to the origin of new haplotypes. The same authors identify the area of Southern France, the Iberian Peninsula and the area south of S. Petersburg as refugial areas. Based on our results, it seems that Italy could have been a refuge area as well. The available data did not allow to delineate a clear geographic characterisation of $T$. piniperda populations, as shown by Ritzerow et al. [24]. This can be explained by both the lower number of bp used in our analysis and by the addition of the new Italian haplotypes. The only consideration deals with the haplotypes 1 and 2, which are the most common in Europe and probably the most ancient haplotypes of the taxon.

Little information exists about the migration routes of most $T$. piniperda haplotypes. It has been suggested that a parallel evolution occurred between $T$. piniperda and its main host, $P$. sylvestris, which has a very large and continuous distribution covering all Europe and Asia [9, 24]. That gives to the insect the possibility to move along both east-west and north-south directions. In addition, we suggest that the increase of the international trade of pine wood is responsible of insect movement among countries and even continents. In this concern, Ritzerow et al. [24] reported that the populations of $T$. piniperda found in North America were introduced from Europe, based on haplotype identity. Following the previous considerations, the low genetic structure of $T$. piniperda seems to be due to both the large and continuous range of its main host and to the intensive trade of timber among different countries, which led to a general mixing of haplotypes coming from different populations.

Acknowledgements: The work has been supported by a grant MIURPRIN 2001 to L. Masutti. The authors are very grateful to Diego Gallego, Christian Stauffer and two anonymous reviewers for the critical revision of the manuscript and for their precious advise. A special thank to Tomaso Patarnello and Lorenzo Zane for the use of laboratories and facilities.

\section{REFERENCES}

[1] Arbogast B.S., Kenagy G.J., Comparative phylogeography as an integrative approach to historical biogeography, J. Biogeogr. 28 (2001) 819-825.

[2] Avise J.C., Phylogeography: the history and formation of species, Harvard University Press, Cambridge, MA, USA, 2000.

[3] Balachowsky A., Faune de France: Coléoptères Scolytides, Faune de France, 50, Libraire de la Faculté des Sciences, Paris, 1949.

[4] Carle P., Problèmes posés par les ravageurs xylophages des conifères en forêt méditerranéenne, Rev. For. Fr. 27 (1975) 283-296.

[5] Chararas C., Étude biologique des scolytides des conifères, Enc. Ent. 37, Lechevalier, Paris, 1962.

[6] Clark A.G., Neutrality tests of highly polymorphic restriction-fragment-length polymorphisms, Am. J. Hum. Genet. 41 (1987) 948956.
[7] Critchfield W.B., Little E.L. Jr., Geographic distribution of the pines of the World. USDA, For. Serv. Misc. Publ., 1966.

[8] Del Favero R., De Mas G., Ferrari C., Gerdol R., Lasen C., Masutt L., De Battisti R., Paiero P., Colpi C., Urso T., Zanotto S., Le pinete litorali nel Veneto, Regione del Veneto, Multigraf (VE), 1989.

[9] Duan Y., Kerdelhué C., Ye H., Lieutier F., Genetic study of the forest pest Tomicus piniperda (Col., Scolytinae) in Yunnan province (China) compared to Europe: new insights for the systematics and evolution of the genus Tomicus, Heredity 93 (2004) 416-422.

[10] Ewens W.J., The sampling theory of selectively neutral alleles, Theor. Popul. Biol. 3 (1972) 87-112.

[11] Gallego D., Galian J., The internal transcribed spacers (ITS1 and ITS2) of the rDNA differentiates the bark beetle forest pests Tomicus destruens and T. piniperda, Insect Mol. Biol. 10 (2001) 415420.

[12] Gil L., Pajares J.A., Los escolitidos de las coniferas en la Peninsula Iberica, Publicaciones del Ministerio de Agricultura, Pesca y Alimentacion - Secretaria General Tecnica, Madrid, 1986.

[13] Haack R.A., Kucera D., New introduction - Common pine shoo beetle, Tomicus piniperda (L.), USDA For. Serv., north-eastern area, pest alert, NA-TP-05-93, 1993.

[14] Hewitt G., The genetic legacy of the Quaternary ice ages, Nature 405 (2000) 907-913.

[15] Kerdelhué C., Roux-Morabito G., Forichon J., Chambon J.-M., Robert A., Lieutier F., Population genetic structure of Tomicus piniperda (Curculionidae: Scolytinae) on different pine species and validation of T. destruens (Woll.), Mol. Ecol. 11 (2002) 483-494.

[16] Kohlmayr B., Riegler M., Wegensteiner R., Stauffer C., Morphological and genetic identification of the three pine pests of the genus Tomicus (Coleoptera, Scolytidae) in Europe, Agric. For. Entomol. 4 (2002) 151-157.

[17] Kumar S., Tamura K., Jakobsen I.B., Nei M., MEGA 2.1, Molecular Evolutionary Genetics Analysis Software, Bioinformatics, 2001.

[18] Lekander B., On Blastophagus destruens Woll. and a description of its larva (Col. Scolytidae), Entomol. Tidskr. 92 (1971) 271-276.

[19] Masutti L., Pinete dei litorali e Blastophagus piniperda L. - Una difficile convivenza, Monti e Boschi 3 (1969) 15-27.

[20] Patwary M.U., Kenchington E.L., Bird C.J., Zouros E., The use of random amplyfied polymorphic DNA markers in genetic studies of the sea scallop Plactopecten magellanicus (Gmellin, 1791), J. Shell Res. 13 (1994) 547-553.

[21] Pfeffer A., Zentral- und westpaläarktische Borken- und Kernkäfer (Coleoptera: Scolytidae, Platypodidae), Pro Entomologica, Naturhistorisches Museum Basel, 1995.

[22] Posada D., Crandall K.A., Templeton A.R., GeoDis: a program for the cladistic nested analysis of the geographical distribution of genetic haplotypes, Mol. Ecol. 9 (2000) 487-488.

[23] Postner M., Scolytidae Borkenkäfer, in: Schwenke W. (Ed.), Die Forstschädlinge Europas, Bd. 2, Käfer, Verlag Paul Parey, Hamburg und Berlin, 1974.

[24] Ritzerow S., Konrad H., Stauffer C., Phylogeography of the Eurasian pine shoot beetle Tomicus piniperda (Coleoptera: Scolytidae), Eur. J. Entomol. 101 (2004) 13-19.

[25] Russo G., Il blastofago del pino (Blastophagus (Myelophilus) piniperda L. var. rubripennis Reitter), R. Lab. Entomol. Agr., Fac. di Agraria di Portici 19 (1940) 1-13.

[26] Russo G., Scolitidi del Pino del litorale toscano, Boll. Ist. Entomol. “G. Grandi”, Univ. Bologna 15 (1946) 297-314.

[27] Schedl K.E., Scolytidae, Platypodidae, in: Winkler A. (Ed.), Catalogus Coleopterorum Regionis Palaearctica, Wien, 1932, pp. 1632 1647. 
[28] Schneider S., Roessli D., Excoffier L., Arlequin ver. 2.000: a software for population genetic data analysis, University of Geneva, Geneva, 2000.

[29] Simon C., Frati F., Beckenbach A., Evolution, weighting and phylogenetic utility of mitochondrial gene sequences and phylogenetic utility of mitochondrial gene sequences and a compilation of conserved polymerase chain reaction primers, Ann. Entomol. Soc. Am. 87 (1994) 651-701.

[30] Simonsen K.L., Churchill G.A., Aquadro C.F., Properties of Statistical Tests of Neutrality for DNA Polymorphism Data, Genetics 141 (1995) 413-429.

[31] Stauffer C., Lakatos F., Hewitt G.M., Phylogeography and postglacial colonization routes of Ips typographus L. (Coleoptera, Scolytidae), Mol. Ecol. 8 (1999) 763-773.

[32] Tajima F., Statistical method for testing the neutral mutation hypothesis by DNA polymorphism, Genetics 123 (1989) 585-595.

[33] Templeton A.R., Boerwinkle E., Sing C.F., A cladistic analysis of phenotypic associations with haplotypes inferred from restriction endonuclease mapping. I. Basic theory and an analysis of alcohol dehydrogenase activity in Drosophila, Genetics 117 (1987) 343351 .
[34] Templeton A.R., Crandall K.A., Sing C.F., A cladistic analysis of phenotypic associations with haplotypes inferred from restriction endonuclease mapping and DNA sequence data. III. Cladogram estimation, Genetics 132 (1992) 619-633.

[35] Templeton A.R., Sing C.F., A cladistic analysis of phenotypic associations with haplotypes inferred from restriction endonuclease mapping. IV. Nested analyses with cladogram uncertainty and recombination, Genetics 134 (1993) 659-669.

[36] Templeton A.R., Statistical phylogeography: methods of evaluating and minimizing inference errors, Mol. Ecol. 13 (2004) 789809 .

[37] Thompson J.D., Gibson T.J., Plewniak F., Jeanmougin F., Higgins D.G., The Clustal X windows interface: flexible strategies for multiple sequence alignment aided by quality analysis tools, Nucleic Acids Res. 24 (1997) 4876-4882.

[38] Triggiani O., Tomicus (Blastophagus) piniperda (Coleoptera, Scolytidae, Hylesininae): biologia, danni e controllo nel litorale ionico, Entomologica 19 (1984) 5-21.

[39] Watterson G.A., The homozygosity test of neutrality, Genetics 88 (1978) 405-417. 